\title{
EVALUATION OF LOCAL IDENTITY IN KATAMAMA HOTEL BUILDING EXPRESSION IN SEMINYAK, BALI
}

\author{
${ }^{1}$ Sonia Zipora. ${ }^{2}$ Dr. Ir. Bachtiar Fauzy, M.T. \\ ${ }^{1}$ Student in the Bachelor's (S-1) Study Program in Architecture \\ at Parahyangan Catholic University \\ ${ }^{2}$ Senior lecturer in the Bachelor's (S-1) Study Program in Architecture \\ at Parahyangan Catholic University
}

\begin{abstract}
The times have created an identity crisis that has led to the fading of cultural diversity. This has caused many buildings in Indonesia today that have acted on behalf of or made the building have a local identity to reflect culture. The local identity used should not only be in the physical part of the building, but also have concepts and meanings applied. One of the local identity can be reflected through the expression of the building. A good building expression is a building that can pay attention to the local identity of the local culture in the building.

This study aims to determine the local identity contained in the object of study, related to the expressions observed by observers. The object of study needs to be examined and studied further about the concept of Tri Angga used, and the representation of Bali that is reflected through the building, so that it can be known whether the object of study displays local Balinese identity or not. This evaluation discusses the conclusions of local identity in the case study building expressions and what should be done so that the local identity of Bali is more felt in the object of research.

The theory used to support this research is the evaluation of architecture, local identity, architectural expression, identity and expression of Balinese architecture. The expression theory uses the Building Quality Theory by Kevin Lynch in 1960. The aspects of expression theory are chosen according to the explanations relevant to the object of study, form simplicity, visual scope, directional differentiation, and dominance. The method used in this study uses qualitative methods with descriptive, analytic, and interpretative approaches.

The results of the study were to evaluate the local identity contained in the Katamama Hotel building expressions, which were assessed based on the theory of building quality. Local identity in the research object is in the aspect of dominance / dominance. The identity used is only found in the Bali brick material used in the scope of the building. Katamama Hotel does not use Balinese concepts, which rights are a characteristic or identity of Balinese architecture. The quality of buildings such as visual scope in the shape of the building is the main expression to be displayed. The brick material with gaps obtained from the brick structure makes a visual impression that can be felt by visitors, and is in accordance with the concept designed by the architect of the building by paying attention to lighting and shadows. While the quality of directional differentiation and form simplicity in buildings, both the shape of the building and the arrangement of the space become an aspect that is less attention to the Katamama Hotel.

The benefit of this research is to provide an in-depth understanding of local identity and the importance of maintaining local wisdom, educating the public about the expression and its relation to local architectural identity with examples of real objects, so that physical and non-physical elements can be seen, enriching knowledge, especially culture local archipelago, as well as adding theoretical study studies on local expression and identity, as well as their relation to national identity.
\end{abstract}

Key words: Evaluation, local identity, expression, Bali

\section{EVALUASI IDENTITAS LOKAL PADA EKSPRESI BANGUNAN HOTEL KATAMAMA DI SEMINYAK, BALI}

\author{
${ }^{1}$ Sonia Zipora. ${ }^{2}$ Dr. Ir. Bachtiar Fauzy, M.T. \\ ${ }^{1}$ Mahasiswa S1 Program Studi Arsitektur Universitas Katolik Parahyangan. \\ 2 Dosen Pembimbing S1 Program Studi Arsitektur Universitas Katolik Parahyangan.
}

\footnotetext{
${ }^{1}$ Corresponding Author: 4216039@student.unpar.ac.id
} 


\begin{abstract}
Abstrak- Perkembangan zaman membuat krisis identitas yang menyebabkan pudarnya keberagaman budaya. Hal itu menyebabkan banyak bangunan di Indonesia sekarang ini yang mengatasnamakan atau membuat bangunannya memiliki identitas lokal untuk mencerminkan budaya. Identitas lokal yang dipakai seharusnya bukan saja berada pada bagian fisik bangunan, tetapi juga memiliki konsep dan makna yang diterapkan. Identitas lokal salah satunya dapat tercermin lewat ekspresi bangunan. Ekspresi bangunan yang baik adalah bangunan yang dapat memperhatikan identitas lokal budaya setempat pada bangunannya.

Penelitian ini memiliki tujuan untuk mengetahui identitas lokal yang terdapat pada objek studi, terkait dengan ekspresi yang diamati oleh para pengamat. Objek studi perlu diteliti dan dikaji lebih jauh mengenai konsep Tri Angga yang dipakai, dan representasi Bali yang tercermin lewat bangunannya., sehingga dapat diketahui apakah objek studi menampilkan identitas lokal Bali atau tidak. Evaluasi ini membahas mengenai kesimpulan identitas lokal pada ekspresi bangunan kasus studi dan hal yang seharusnya dapat dilakukan agar identitas lokal Bali lebih terasa pada objek penelitian.

Teori yang dipakai untuk menunjang penelitian ini adalah evaluasi arsitektur, identitas lokal, ekspresi arsitektur, identitas dan ekspresi arsitektur Bali. Teori ekspresi menggunakan Teori Kualitas Bangunan oleh Kevin Lynch tahun 1960. Aspek-aspek teori ekspresi dipilih sesuai dengan penjelasan yang relevan dengan objek studi, yaitu kesederhanaan bentuk/form simplicity, lingkup visual/visual scope, pembeda arah/directional differentiation, dan dominasi/dominance. Metode yang digunakan dalam penelitian ini menggunakan metode kualitatif dengan pendekatan deskriptif, analitik, dan interpretatif.

Hasil penelitian adalah untuk mengevaluasi identitas lokal yang terdapat pada ekspresi bangunan Hotel Katamama, yang dikaji berdasarkan teori kualitas bangunan. Identitas lokal pada objek penelitain terdapat pada aspek dominasi/dominance. Identitas yang digunakan hanya terdapat pada material batu bata Bali yang digunakan di pelingkup bangunan. Hotel Katamama tidak menggunakan konsep-konsep Bali, yang mana hak tersebut merupakan karakteristik atau identitas arsitektur Bali. Kualitas bangunan seperti visual scope pada bentuk bangunan adalah ekspresi utama yang ingin ditampilkan. Material batu bata dengan celah yang didapat dari susunan bata membuat kesan visual yang bisa dirasakan oleh para pengunjung, dan sesuai dengan konsep yang dirancang oleh arsitek bangunan dengan memperhatikan pencahayaan dan bayangan. Sedangkan kualitas directional differentiation dan form simplicity pada bangunan, baik bentuk bangunan dan susunan ruang menjadi suatu aspek yang kurang menjadi perhatian pada Hotel Katamama.

Manfaat penelitian ini memiliki tujuan untuk memberikan pengertian secara mendalam mengenai identitas lokal dan pentingnya menjaga kearifan lokal,mengedukasi masyarakat tentang ekspresi dan kaitannya dengan identitas lokal arsitektur lokal dengan contoh objek nyata, sehingga dapat terlihat unsur fisik dan nonfisik, memperkaya pengetahuan, khusunya budaya lokal nusantara, serta menambah kajian studi teoritik tentang ekspresi dan identitas lokal, serta kaitanya dengan identitas bangsa.
\end{abstract}

Kata-kata kunci: Evaluasi, identitas lokal, ekspresi, Bali

\title{
1. PENDAHULUAN
}

\subsection{LATAR BELAKANG}

Perkembangan zaman dalam satu sisi dapat menjadi suatu hal yang baik, tetapi juga ada sesuatu yang hilang bersamaan dengan perkembangan zaman. Hal yang hilang ini merupakan identitas atau ciri khas budaya setiap daerah yang dulunya beragam kini menjadi 'kabur'. Maksud dari ciri khas budaya adalah identitas lokal yang sudah tidak lagi dipertahankan dan dilestarikan keadaannya. Setiap makna budaya yang dulunya terwujud lewat desain bangunannya, sekarang tergantikan oleh desain yang tidak lagi memperlihatkan dan memperindah keragaman budayanya. Krisis identitas budaya ini juga menjadi masalah penting di Indonesia.

Indonesia merupakan negara kesatuan yang memiliki kekayaan alam dan keragaman budaya yang berlimpah. Setiap daerahnya memiliki ciri khas budaya masing-masing yang diwujudkan, salah satunya lewat arsitektur. Akan tetapi, tuntutan zaman dan globalisasi membuat nilai lokal tersebut menjadi pudar dan keberadaannya menjadi sulit untuk dicari. Perkembangan zaman dan arus globalisasi tidak dapat dihindari, tetapi harus disesuaikan dan diolah sesuai dengan identitas Indonesia sendiri.

Oleh karena itu, banyak bangunan di Indonesia sekarang ini yang mengatasnamakan dan membuat bangunannya memiliki identitas lokal yang mencerminkan budaya. Identitas lokal yang dipakai seharusnya bukan saja berada pada bagian fisik bangunan, tetapi juga memiliki 
konsep dan makna yang diterapkan. Pentingnya identitas lokal di zaman sekarang ini harus diperhatikan, bukan hanya bangunan yang mengambil sebagian dari budaya, melainkan menerapkan konsep identitas lokal menjadi bagian yang penting, sehingga keberagaman budaya yang menjadi identitas bangsa Indonesia dapat dipandang secara keseluruhan, bukan hanya terlihat dalam satu aspek saja. Identitas lokal salah satunya dapat tercermin lewat ekspresi bangunan. Ekspresi bangunan yang baik adalah bangunan yang dapat memperhatikan identitas budaya setempat pada bangunannya.

Pulau Bali merupakan salah satu budaya Indonesia yang memiliki adat istiadat dan kepercayaan yang sangat tinggi. Budaya tersebut tercermin dari masyarakat, hingga arsitekturnya. Banyaknya para wisatawan dan turis yang datang, menjadikan pulau Bali sebagai potensi agar identitas lokal terus berkembang, salah satunya lewat arsitektur. Pulau Bali selalu melakukan pembangunan, khususnya tempat penginapan atau hotel. Banyak bangunan yang memakai dan mengklaim bahwa bangunan yang dibuat sesuai menggunakan penerapan arsitektur lokal Bali.

Hotel Katamama adalah salah satu hotel di Seminyak, Bali yang banyak diberitakan bahwa Hotel Katamama disebut sebagai representasi Bali, dengan bagian eksteriornya menggunakan konsep Tri Angga, dimana terdapat keharmonisan antara bangunan dengan penghuninya. Selain itu, material yang digunakan menggunakan material dengan ciri khas Bali dan dibuat langsung oleh para pengrajin lokal di Bali. Penerapan arsitektur Bali bukan hanya dilihat dari satu aspek saja, melainkan dari susunan konsep yang sesuai dengan arsitektur Bali, maupun dari ekspresi identitas lokal yang tercermin pada bangunan. Oleh karena itu, evaluasi identitas lokal pada ekspresi pada suatu bangunan perlu diperhatikan dan diterapkan secara benar dan mendalam lewat contoh bangunan nyata arsitekturnya. Hotel Katamama yang ada di pulau Bali perlu diteliti dan dikaji lebih jauh mengenai ekspresi identitas lokal yang dicerminkan, konsep Tri Angga pada eksterior bangunannya, dan hal yang seharusnya dapat lebih dikembangkan oleh Hotel Katamama terkait dengan arsitektur Bali.

\subsection{PERUMUSAN MASALAH}

Hotel Katamama perlu dikaji lebih mandalam mengenai arsitektur lokal dan modern yang dimiliki oleh bangunan tersebut, sehingga jelas ekspresi dan makna simbolis yang terkandung pada Hotel Katamama di Seminyak, Bali.

Rumusan masalah dari penelitian tersebut dapat diuraikan sebagai berikut:

1. Bagaimana evaluasi identitas lokal pada ekspresi bangunan Hotel Katamama di Seminyak, Bali?

\subsection{TUJUAN PENELITIAN}

\section{Tujuan dari penelitian ini adalah sebagai berikut:}

1. Memberikan pengertian tentang evaluasi identitas lokal dan ekspresi dalam arsitektur.

2. Mengidentifikasi ekspresi bangunan Hotel Katamama di Seminyak, Bali.

3. Mengungkapkan evaluasi identitas lokal pada ekspresi bangunan Hotel Katamama di Seminyak, Bali.

\subsection{MANFAAT PENELITIAN}

\section{Manfaat yang dihasilkan dari penelitian ini, sebagai berikut:}

1. Memberikan pengertian secara mendalam mengenai identitas lokal dalam ekspresi bangunan dan pentingnya menjaga kearifan lokal.

2. Mengedukasi masyarakat tentang ekspresi dan kaitannya dengan identitas lokal arsitektur lokal dengan contoh objek nyata, sehingga dapat terlihat unsur fisik dan non-fisik.

3. Memperkaya pengetahuan, khusunya budaya lokal nusantara.

4. Menambah kajian studi teoritik tentang ekspresi dan identitas lokal yang disampaikan dan kaitanya dengan identitas bangsa. 


\subsection{RUANG LINGKUP}

Ruang lingkup berperan sebagai acuan batasan pembahasan ruang lingkup teori dan objek penelitian yang akan dikaji lebih dalam sesuai dengan isu permasalahan dan topik penelitian yang dipilih. Ruang lingkup dibagi menjadi ruang lingkup kajian dan ruang lingkup objek.

\section{- Ruang Lingkup /Aspek Kajian}

Penelitian ini dikaji menggunakan deskriptif, analitik, dan interpretatif. Deskriptif dan analitik membahas dan menganalisis permasalahan di lapangan sesuai berdasarkan fakta-fakta dan kenyataan yang dapat dipertanggungjawabkan. Objek dijelaskan dan ditampilkan secara jelas secara interpretatif, mengacu pada literatur dan referensi yang dipercaya kebenarannya. Lingkup kajian mengutamakan objek Hotel Katamama di Seminyak, Bali.

Batasan teori yang dijabarkan adalah literatur tentang teori tentang evaluasi, identitas lokal, ekspresi arsitektur, teori ordering principles, serta ekspresi dan identitas arsitektur Bali. Kajian yang dibahas menggunakan teori dari Kevin Lynch tentang kualitas bangunan, dengan menggunakan unsur-unsur yang dianggap sesuai dengan objek penelitian. Identitas lokal menjadi suatu aspek yang penting, apakah di setiap unsur tersebut memperhatikan identitas lokal atau tidak..

\section{- Ruang Lingkup Kasus Studi}

Lingkungan objek yang akan dibahas berlokasi di Jl. Petitenget No.51, Kerobokan Kelod, Kuta Utara, Kabupaten Badung, Bali, Indonesia. Objek ini didesain oleh arsitek Andra Matin, yang memiliki luas $6000 \mathrm{~m}^{2}$. Hotel ini dibuka pada tahun 2015 dengan standar hotel bintang 5. Objek ini dinilai memiliki gagasan desain dengan merepresentasikan kelokalan bali dengan pencampuran gaya modern. Material termasuk lukisan yang ada di hotel tersebut menggunakan material ciri khas Bali dengan lukisan yang dibuat oleh seniman lokal Bali.

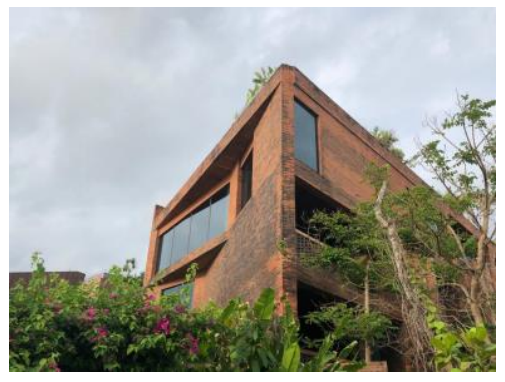

Gambar.1 Tampak Depan Hotel Katamama.

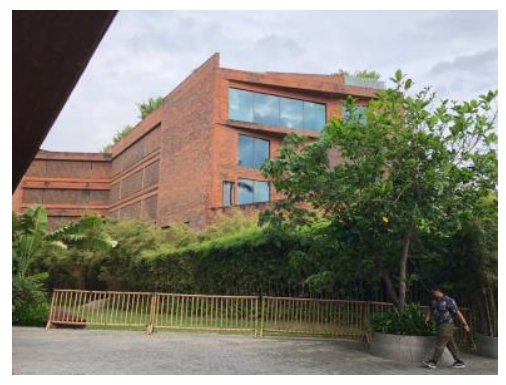

Gambar.2 Perspektif Hotel Katamama

\section{- Kerangka Penelitian}

Kerangka penelitian dimulai dari isu permasalahan banyaknya bangunan saat ini yang mengatasnamakan pencampuran arsitektur lokal dan modern. Hal tersebut perlu dikaji lebih mendalam tentang identitas lokal yang digunakan untuk menampilkan ekspresi yang terkandung pada bangunan tersebut. Bangunan yang memiliki karakteristik lokal pada konsep desainnya, tidak terlihat dari aspek fisiknya saja, namun dari aspek non-fisik pada bangunannya, misalnya konsep yang menampilkan arsitektur Bali pada susunan yang dipakai pada arsitektur lokal. Setelah diketahui rumusan masalah dan tujuan dalam penelitian ini, mencari studi literatur tentang evaluasi arsitektur, identitas lokal, ekspresi arsitektur, identitas dan arsitektur Bali, dan teori ordering principles.

Metode penelitian berupa deskriptif, analitik, dan interpretatif berupa studi literatur dan studi lapangan. Hal yang dilakukan pada saat observasi lapangan yaitu: pengumpulan data, 
pengukuran objek, foto objek, dokumentasi objek, dan sketsa ulang dalam bentuk 2D dan 3D. Analisis dilakukan sesuai dengan metode dan observasi lapangan yang telah dilakukan. Analisis dilakukan dengan acuan teori yang relevan dengan kasus permasalahan objek studi yang akan dibahas dan sesuai dengan studi literatur yang telah dipelajari. Kemudian hasil penelitian membahas mengenai ekspresi Hotel Katamama dan evaluasi identitas lokal pada ekspresi bangunan Hotel Katamama.

\section{KAJIAN TEORI}

Kajian teori berisikan landasan-landasan yang dijadikan acuan dalam menentukan hipotesa dalam penelitian ini.

\section{Evaluasi Arsitektur}

Evaluasi menurut KBBI (Kamus Besar Bahasa Indonesia) adalah memberikan penilaian; menilai. Kata evaluasi berasal dari Bahasa Inggris, yaitu "evaluation" dengan kata awal "value". Istilah evaluasi dipopulerkan oleh F.G Caro (1971) dalam bukunya yang berjudul "Readings in Evaluation Research". Sejak saat itu sebagian evaluasi, peneliti, lembaga pemerintah, dan lembaga swasta menggunakan istilah evaluasi ${ }^{2}$. Arsitektur adalah seni dan ilmu merancang serta membuat konstruksi bangunan, jembatan, dan sebagainya; metode dan gaya rancangan suatu konstruksi bangunan.

Oleh karena itu, evaluasi arsitektur dapat diartikan sebagai suatu penilaian yang ditujukan terhadap gaya rancangan suatu bangunan. Evaluasi arsitektur ini merupakan suatu rincian penilaian yang dilakukan terhadap suatu objek penelitian, sehingga didapatkan suatu kesimpulan tentang nilai-nilai yang terkandung dan nilai yang dapat dipejari dari objek kasus studi.

Proses evaluasi dapat dibagi menjadi 2 bagian, yaitu pre-test yang berada di awal dan post-test yang berada di akhir. Pre-test adalah sebuah penilaian yang dibuat untuk menguji konsep dan eksekusi yang direncanakan, sedangkan post-test adalah suatu penilaian yang dibuat untuk melihat proses dan hasil pencapaian. Evaluasi pada penelitian ini bersifat posttest dan bertujuan untuk memperbaiki dan mengembangkan suatu hal yang dianggap keliru dan perlu untuk dikaji lebih mendalam, sehingga terlihat nilai-nilai yang dijadikan acuan dalam suatu proses.

\section{Identitas Lokal}

Identitas memiliki arti suatu ciri khas atau jati diri yang terkait pada seseorang atau sesuatu objek, sedangkan lokal merupakan sesuatu yang asalnya dari daerah sendiri. Lokal juga sering dikaitkan dengan kebudayaan, setiap daerah asal dimana suatu benda atau bangunan tersebut berada. Identitas lokal dalam arsitektur membahas mengenai identitas atau ciri khas yang dimiliki oleh suatu kebudayaan dalam suatu daerah, yang berhubungan dengan arsitektur, seperti: ornament, tradisi, dan konsep budaya suatu daerah yang digunakan untuk membangun bangunan.

Rumah Gadang dan tatanan massa rumah Bali merupakan salah satu identitas lokal dalam arsitektur. Rumah Gadang merupakan ciri khas arsitektur di Sumatra Barat, dimana bagian atap menjadi salah satu ciri khas yang menonjol. Selain itu, material dan ornamenornamen yang digunakan menjadi ciri khas lokal khas Sumatera Barat. Tatanan massa pada rumah tradisional Bali merupakan suatu konsep yang digunakan oleh masyarakat Bali untuk membangun rumah maupun tempat peribadatan. Setiap daerah memiliki konsep dan adatnya masing-masing yang menerminkan identitas Indonesia.

\footnotetext{
2 Francis, G. Caro. 1971. Readings in Evaluation Research. New York
} 


\section{Teori Ekspresi dalam Arsitektur}

Teori Kualitas bangunan sesuai dengan teori Kevin Lynch (1960, 105-108), perancang bangunan dapat menggambarkan atau menilai bangunan atau lingkungan binaan melalui beberapa aspek kualitas bentuk yang relevan dengan bahasan pnelitian, yaitu ${ }^{3}$ :

- Form Simplicity membahas mengenai kesederhanaan bentuk

- Dominance membahas mengenai dominasi yang ada pada bangunan

- Directional Differentiation membahas mengenai petunjuk arah bangunan

- Visual Scope membahas mengenai kesan visual pada bangunan.

\section{Identitas dan Ekspresi Arsitektur Bali}

Agama dengan kebudayaan menjadi salah satu unsur yang memiliki hubungan erat satu dengan yang lain. Budaya Bali termasuk dengan masyarakatnya membentuk kebudayaan menjadi identitas yang sekarang ini dikenal dibanyak wilayah. Kebudayaan tersebut mengacu pada dua unsur penting, yaitu adanya kesatuan budaya Bali dan kesatuan agama Hindu. Agama Hindu di Bali adalah unsur budaya universal yang menjadi jiwa dan spirit dari kebudayaan Bali. Oleh karena itu, dapat dikatakan bahwa jika tidak adanya agama Hindu, maka kebudayaan Bali kehilangan semangat, identitas, dan jati dirinya (Sujana, 1994; 66) ${ }^{4}$. Identitas lokal Bali dapat diterapkan melalui konsep-konsep arsitektur Bali yang dipercayai turun-temurun sebagai tradisi dalam mengatur tata nilai ruangnya. Konsep Bali yang dipilih dalam teori ini merupakan teori yang relevan dengan kasus objek studi, seperti: konsep Orientasi Kosmologi yang menjadi bagian dari konsep Sanga Mandala, Tri Hita Karana, dan Tri Angga.

\section{Orientasi Kosmologi Bali}

Pengertian orientasi kosmologi terdapat konsepsi sanga (sanga mandala / nawa sanga). Konsepsi ini bermula dari perpaduan astha dala ( 8 penjuru mata angin) dengan dewata nawa sanga (sembilan mitologi dewa-dewa penguasa mata angin). Falsafahnya tetap menitikberatkan dalam rangka menjaga keharmonisan dan keselarasan alam. Orientasi Kosmologi merupakan sumbu yang terdapat dalam setiap bangunan lokal di Bali, yang biasa digunakan sebagai aturan dalam menata ruang, yang menggunakan unsur alam sebagai suatu sumbu/patokannya ${ }^{5}$. Orientasi kosmologi ini terdiri dari tiga sumbu, yaitu:

- Sumbu Kosmos Bhur, Bhuwah dan Swah (hidrosfir, litosfir, dan atmosfir)

- Sumbu Ritual Kangin-Kauh (terbit dan terbenamnya matahari)

- Sumbu Natural Kaja-Kelod (gunung dan laut).

Masyarakat Bali menjadikan pegunungan sebagai petunjuk arah. Salah satu gunung yang dijadikan orientasi utama adalah Gunung Agung. Posisi pegunungan yang berada di bagian tengah pulau Bali menyebabkan daerah seakan terbagi menjadi dua bagian, yaitu Bali Utara dan Bali Selatan. Oleh sebab itu, pengertian kaja bagi masyarakat Bali yang tinggal di sebelah utara dengan sebelah selatan menjadi berbeda, meskipun patokan sumbu mereka tetap, yaitu sumbu kaja-kelod dan kangin-kauh.

\section{Konsep Tri Hita Karana}

Konsep ini mengedepankan tiga unsur yang menjadi perantara antara alam dan manusia untuk terciptanya kesempurnaan hidup, yaitu unsur jiwa, raga, dan tenaga. Ketiga hal tersebut akan menjadi sumber kebahagiaan dengan memperhatikan keharmonisan antara manusia

\footnotetext{
${ }^{3}$ Lynch, Kevin. 1960. The Image of the City. MIT Press, Cambridge

4 Sujana, Nyoman Naya. 1994. Manusia Bali Dipersimpangan Jalan. Denpasar: Balai Pustaka

5 Dwijendra, Ngakan Ketut Acwin. 2008. Arsitektur Rumah Tradisional Bali: Berdasarkan Asta Kosala-Kosali. Denpasar: Udayana University Press dan CV. Bali Media Adhikarsa
} 
dengan sesama, dan yang terakhir memperhatikan hubungan antara manusia dengan alam. Tri Hita Karana membuat tiga unsur dasar dalam konsepnya, diantaranya ${ }^{6}$ :

\section{- Parahyangan}

Semua hal yang mengatur hubungan yang berkaitan dengan keTuhanan khusunya kepercayaan dan agama Hindu dalam memuja Tuhannya.

- Pawongan

Semua hal yang mengatur hubungan antar sesama sehingga terjadi kesejahteraan, kebaikan, kerukunanlah yang terjadi.

- Palemahan

Semua hal yang merupakan wilayah dimana manusia hidup dengan menjaga lingkungan sekitarnya.

\section{Konsep Ruang Tri Angga}

Tri Angga merupakan konsep dasar yang melandasi Tri Hita Kirana. Dalam arsitektur hunian dan daerah pemukiman, tri angga adalah pengolahan tata ruang yang mengutamakan aspek kenyamanan, keselarasan, dan keharmonisan manusia dengan sekitarnya, dalam artian lingkungannya, baik skala kecil hingga sakala besar. Skala kecil dan besar yang dimaksud adalah dari tingkat rumah tinggal sederhana hingga kawasan besar, misalnya desa atau kawasan pemukiman.

Konsep ini terbagi menjadi 3 zona penting, yaitu:

- Utama Angga yang memiliki arti gunung/atas/kepala/murni;

- Madya Angga yang memiliki arti dataran/tengah/badan/netral

- Nista Angga yang memiliki arti lautan/bawah/kaki/kotor

Konsep Tri Angga digunakan untuk fungsi hunian dan peribadatan. Fungsi hunian ini dapat direalisasikan sebagai pola rumah maupun pola desa. Konsep Tri Angga ini menjadi suatu konsep Bali yang paling banyak diketahui dan menjadi konsep dasar yang mendasari Tri Hita Karana. Konsep Tri Angga ini mengutamakan kenyamanan, keselarasan dan keharmonisan yang dibuktikan keberadaannya dengan 3 bagian tersebut (utama, madya, dan nista).

Dr. I.B.G. Pujaastawa, M,A. (2014:4) mengungkapkan bahwa kebudayaan Bali sebenarnya merupakan ekspresi dari hubungan interaksi orang Bali dengan lingkungannya. Masyarakat Bali membedakan lingkungannya menjadi dua macam, yaitu lingkungan sekala (nyata) dengan lingkungan niskala (tidak nyata). Lingkungan niskala adalah lingkungan yang berhubungan dengan keagamaan/spiritual yang berhubungan dengan ritual keagaamaan, upacara, hingga fasilitas keagamaan, sedangkan lingkungan sekala yaitu lingkungan sosial masyarakat dan lingkungan alam sekitarnya ${ }^{7}$. Lingkungan sosial masyarakat dapat dijumpai lewat norma-norma yang berlaku, bahasa Bali, hingga pranata yang berkaitan dengan masyarakat, sedangkan lingkungan fisik/alam sekitar membuat adanya kaitan antara manusia dengan alam seperti orientasi kosmologi.

Oleh karena itu, ekspresi yang ditampilkan oleh kebudayan Bali yaitu interaksi manusia dengan lingkungan sekala/nyata (lingkungan sosial, dan lingkungan fisik/alam sekitar) dan lingkungan niskala/tidak nyata. Ekspresi tersebut salah satunya digambarkan lewat arsitektur Bali. Adanya konsep-konsep Bali seperti: konsep Tri Angga, Tri Hita Karana, dan Sanga Mandala adalah penerapan interaksi antara manusia dengan lingkungan nyata dan tidak nyata lewat arsitektur. Ekspresi arsitektur Bali dapat dirumuskan dalam prinsip dasar / ordering

6 Bandem, Putu Dupa. 2010. Tri Hita Karana dan Tat Twam Asi. (Online) https://pandejuliana.wordpress.com/2012/01/20/tri-hita-karana-dan-tat-twam-asi/ [diakses tanggal 4 Februari 2020]

7 I.B.G. Pujaastawa. (2014). Kebudayaan Bali. Makalah. 
principles sebagai salah satu cara untuk mencerminkan identitas arsitektur Bali yang dapat dilihat dari ciri fisik bangunannya.

\section{Teori Prinsip Dasar/Ordering Principles}

Prinsip dasar yang menjadi patokan dalam teori D.K Ching hanya diambil yang relevan dengan objek, dalam bukunya yang berjudul "Form, Space, and Order" ${ }^{8 ", ~ y a i t u: ~}$

a. Sumbu

Sumbu pada arsitektur Bali dapat dilihat berdasarkan hirarki/orientasi kosmologi (lautgunung). Sumbu ini dibuat berhubungan dengan sumbu keagamaaan. Sumbu keagamaan yang dimaksud ini berdekatan dengan prinsip dasar hirarki, dimana sumbu dibuat berdasarkan posisi dari yang paling rendah, hingga posisi yang paling tinggi. Posisi yang paling tinggi dalam bangunan Bali yaitu pura, sebagai interaksi antara manusia dengan keTuhanan. Sumbu yang digunakan pada arsitektur Bali adalah sumbu diagonal yang mengarah dari fungsi nista ke fungsi yang utama.

b. Simetri

Rumah arsitektur Bali memiliki beberapa massa bangunan dalam 1 tapak. Setiap massa bangunan tersebut memiliki bentuk bujur sangkar, baik berenetuk persegi, maupun persegi panjang. Hal tersebut membuat bangunan Bali memiliki ekspresi yang sederhana, dapat dilihat dari bentuk bangunan yang mudah dipahami dan memiliki kesimetrisan bentuk. Prinsip dasar simetris ini dapat dibahas pada teori ekspresi bangunan tentang aspek form simplicity. Kesimetrisan ini bukan berarti menjadi menggambarkan identitas lokal Bali secara keseluruhan, melainkan kesimetrisan menjadi salah satu aspek dari beberapa aspek lain dalam mencerminkan identitas lokal arsitektur Bali.

c. Hirarki

Bali memiliki budaya dan agama yang berhubungan kuat, sehingga adat istiadat maupun bangunannya mencerminkan identitas yang berkaitan dengan keTuhanan. Hubungan antara manusia dengan keTuhanan menjadi bagian yang penting/utama, yang dapat terlihat dari adanya suatu area khusus untuk penyembahan. Sebagian besar bangunan di Bali memiliki pura, yang menjadi salah satu identitas budayanya. Oleh karena itu, pentingnya area penyembahan/pura tersebut menjadi suatu hirarki yang menjadi perhatian khusus dalam budaya Bali. Perletakan area penyembahan tersebut berada di bagian utama dan berada jauh dengan area nista/area dapur dan servis. Hirarki pada arsitektur Bali memberikan ekspresi adanya perlakuan khusus antara hubungan manusia dengan Tuhannya, dalam hal ini berkaitan dengan zonasi dan perletakan yang dibedakan.

\section{d. Datum}

Datum pada arsitektur Bali dapat dilihat dari natah (halaman tengah) dan tembok penyengker pada arsitektur rumah Bali. Natah berada di bagian tengah sebagai pemersatu massa-massa bangunan yang terdapat dalam satu tapak. Adanya natah juga memberikan penghawaan alami yang lebih terasa. Tembok penyengker berfungsi sebagai penyatu massa dalam tapak arsitektur Bali dan dipercayai memiliki makna spiritual. Ekspresi tersebut dapat ditemukan pada aspek kesederhanaan bentuk/form simplicity pada teori kualitas bangunan.

${ }^{8}$ Ching, Frank. 2007. Architecture - Form, Space \& Order. New Jersey: John Wiley \& Sons, Inc. 


\section{Kerangka Konseptual}

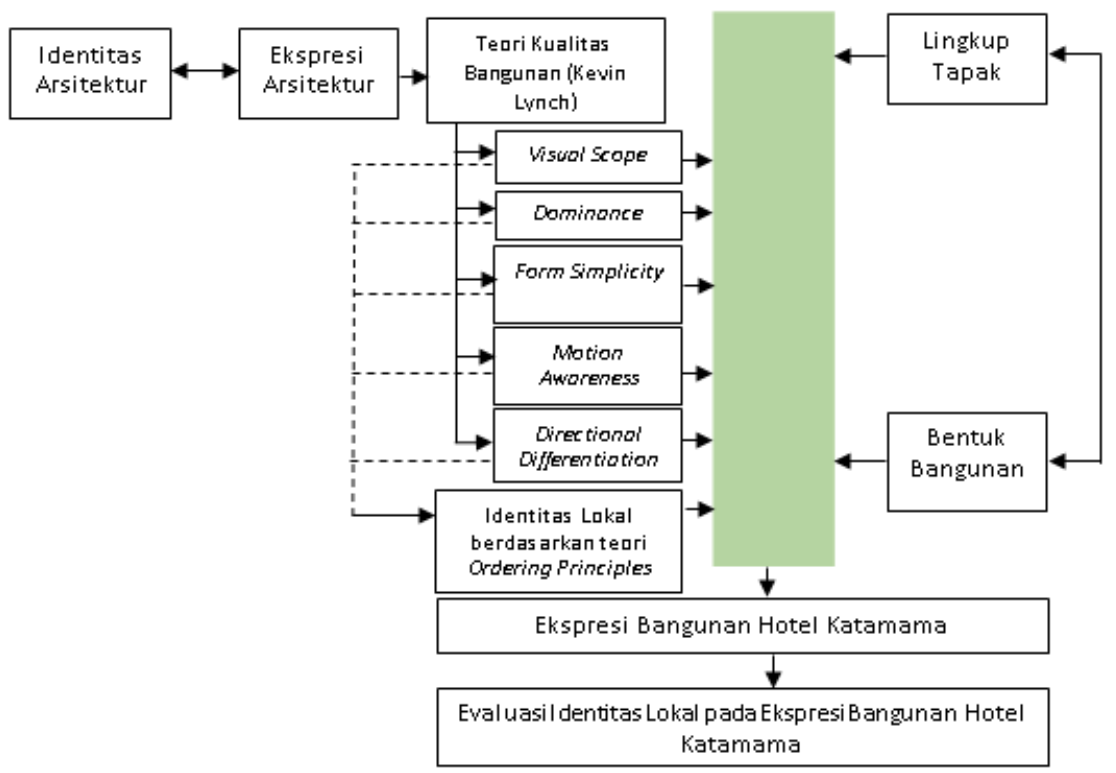

Gambar.3 Diagram Kerangka Konseptual

Kerangka konseptual terdiri dari aspek-aspek yang dibahas pada tahap analisis. Pembahasan mengenai evaluasi identitas lokal didapat dari teori Kualitas Bangunan yang dikemukakan oleh Kevin Lynch. Teori tersebut terdapat beberapa aspek yang digunakan untuk membahas permasalahan, yaitu lingkup visual/visual scope, dominasi/dominance, kesederhanaan bentuk/form simplicity, dan pembeda arah/directional differentiation, sedangkan lingkup objek yang akan dibahas terdiri dari lingkup tapak dan bentuk bangunannya. Ekspresi identitas lokal arsitektur Bali dibantu oleh teori Ordering Principles, sehingga diketahui ekspresi dasar yang ditampilkan oleh arsitektur Bali.

\section{METODE PENELITIAN}

Metode penelitian termasuk penelitian kualitatif dengan pendekatan deskriptif, analitik, dan interpretatif. Deskriptif dilakukan dengan menjelaskan suatu perkara atau kejadian, dalam penelitian ini adalah menjelaskan elemen-elemen bangunan. Menurut Sugiono (2009:29) mengatakan bahwa deskriptif adalah suatu metode yang digunakan untuk memberikan gambaran terhadap objek penelitian melalui data-data yang dikumpulkan, sedangkan analitis dan interpretatif disini berarti memusatkan permasalahan yang ada saat penelitian dilangsungkan, kemudian hasil penggambaran tersebut diolah, dan dianalisis sehingga membuat kesimpulan dan pandangan baru.

\section{Langkah-langkah Alur Penelusuran}

Alur penelusuran terbagi menjadi 2 kajian, yaitu kajian teoritik dan kajian analisa. Kajian teoritik dibuat berdasarkan teori yang menjadi acuan dalam membangun kerangka konseptual, yaitu teori kualitas bangunan yang dikemukakan oleh Kevin Lynch, dan dibantu oleh teori Ordering Principles untuk menemukan ekspresi identitas lokal pada arsitektur Bali. . Bagian kedua yaitu tahapan analisa. Kajian analisa ini adalah sebuah bahasan yang diperoleh ketika penulis sudah melakukan observasi atau percobaan. Kajian ini dibuat ketika sudah memasuki tahap analisis.

Analisis yang dibahas berhubungan dengan ekspresi dan identitas lokal yang kemudian digabungkan dengan penerapan pada lingkup tapak dan bentuk bangunan Hotel Katamama. Setelah itu, didapat hasil ekspresi identitas lokal Hotel Katamama, kemudian diberikan 
evaluasi mengenai identitas lokal yang terdapat pada ekspresi hotel. Evaluasi juga memberikan arahan dan masukan mengenai hal-hal yang dapat dikembangkan untuk bisa membuat Hotel Katamama memiliki ekspresi identitas lokal yang baik dan benar.

Diagram alur penelusuran ini berkaitan dengan metode penelitian yang dilakukan. Kajian analisa yang dilakukan dalam tahap observasi ini berkaitan dengan metode yang bersifat deskriptif, analitik, dan interpretatif. Deskriptif menjabarkan objek hotel Katamama, kemudian dianalisis (metode analitik) berdasarkan hasil observasi dengan studi literatur. Setelah itu, permasalahan yang telah dikaji dievaluasi dan bertujuan untuk memberikan penilaian mengenai identitas lokal arsitektur Bali pada ekspresi Hotel Katamama.

\section{Jenis Penelitian}

Metode yang digunakan dalam penyusunan penelitian ini adalah kualitatif dengan pendekatan deskripstif, analitik, dan interpretatif, yaitu dengan mendeskripsikan objek studi melalui proses analisa dan memunculkan suatu pandangan maupun tafsiran mengenai hasil pengamatan yang dilakukan dalam penelitian. Ketika metode tersebut sudah dilakukan, maka hasil penelitian dikolerasikan dengan studi literatur untuk mendapatkan jawaban atas pertanyaan penelitian. Hasil jawaban itu dikemukakan melalui temuan baru, kesimpulan, dan saran.

\section{Tempat dan Waktu Penelitian}

Tempat Penelitian

: Hotel Katamama di Seminyak, Bali

Jangka Waktu Penelitian : Februari - April 2020

Tabel.1 Rangkuman Jadwal Penelitian

\begin{tabular}{|l|c|c|c|}
\hline & Februari & Maret & April \\
\hline Studi Literatur & $\sqrt{ }$ & & \\
Observasi & $\sqrt{ }$ & & \\
Pengambilan Data Objek & $\sqrt{ }$ & $\sqrt{ }$ & \\
Analisa & & $\sqrt{ }$ & $\sqrt{ }$ \\
Pengambilan Kesimpulan & & & $\sqrt{ }$ \\
\hline
\end{tabular}

\section{Metode Pengumpulan Data}

Data yang diperlukan untuk membuat penelitian ini dibuat dengan berbagai metode sebagai berikut:

1. Studi Literatur

2. Observasi Langsung pada Objek Studi

3. Dokumentasi

\section{Tahap Analisis Data}

Tahapan pertama yaitu pengumpulan data berupa studi literatur dan pengumpulan data objek berupa gambar kerja, bentuk bangunan, layout ruang, foto, dan video. Studi literatur ini berupa teori evaluasi, identitas lokal, teori ekspresi dan identitas arsitektur Bali, dan teori Ordering Principles. Teori Ordering Principles ini digunakan sebagai konsep dasar untuk menganalisis ekspresi identitas lokal arsitektur Bali. Kemudian ekspresi yang didapat dari teori ordering principles ini dapat digunakan sebagai acuan untuk menganalisis identitas lokal pada ekspresi Hotel Katamama.

Tahapan analisa data ini membahas mengenai ekspresi yang dikaji lewat teori Kualitas Bangunan. Aspek kualitas bangunan yang dikaji ini adalah visual scope, form simplicity, dominance, dan directional differentiation. Tahapan ini menganalisasa ekspresi Hotel katamama dan identitas lokal yang ada pada setiap aspek tersebut. Identitas lokal arsitektur Bali didapat dari hasil analisis dengan teori ordering principles sebagai acuannya. Kemudian 
disimpulkan ekspresi hotel dan identitas lokal yang terdapat pada Hotel Katamama. Selanjutnya melakukan evaluasi mengenai kesimpulan ekspresi tersebut. Tahapan terakhir yaitu menyampaikan hasil dari perumusan masalah dan saran.

Metode dapat dibagi menjadi 3 tahapan, yaitu:

Tabel. 2 Tahapan Metode Penelitian

\begin{tabular}{|c|c|c|}
\hline Tahapan 1 & Tahapan 2 & Tahapan 3 \\
\hline $\begin{array}{l}\text { Pengumpulan Data } \\
\text { Tahap mengumpulkan data } \\
\text { dimulai dari pengamatan } \\
\text { langsung objek penelitian } \\
\text { dan melakukan observasi. } \\
\text { Pengumpulan data ini } \\
\text { dibatasi oleh batasan } \\
\text { permasalahan. }\end{array}$ & \begin{tabular}{|l}
\multicolumn{1}{c}{ Analisis Data } \\
Mendeskripsikan dan \\
menginterpretatifkan \\
identitas lokal \\
arsitektur Bali dengan \\
teori ordering \\
principles \\
Menganalisis ekspresi \\
Hotel Katamama \\
dengan teori kualitas \\
bangunan \\
Mengevaluasi identitas \\
lokal pada ekspresi \\
Hotel Katamama
\end{tabular} & \begin{tabular}{lr}
\multicolumn{3}{c}{ Hasil Penelitian } \\
Menampilkan hasil temuan \\
ekspresi yang ingin \\
ditampilkan oleh Hotel \\
Katamama, memberikan \\
kesimpulan ran \\
menjawab permasalahan \\
penelitian, dan memberikan \\
saran.
\end{tabular} \\
\hline
\end{tabular}

\section{Tahap Pengambilan Kesimpulan}

Kesimpulan diambil berdasarkan hasil observasi dan metoda yang dilakukan dalam proses penelitian. Kesimpulan ini bertujuan untuk menjawab rumusan permasalahan yang menjadi pokok bahasan dalam penelitian ini.

\section{ANALISIS}

Evaluasi yang akan dibahas adalah mengenai identitas lokal yang terdapat pada ekspresi bangunan Hotel Katamama di Seminyak, Bali.

\subsection{LINGKUP TAPAK}

Analisa lingkup tapak pada ekspresi yang akan diteliti mengacu kepada teori Kevin Lynch tentang Teori Kualitas Bangunan yang dikaji dengan objek penelitian, yaitu Hotel Katamama di Seminyak, Bali. Ekspresi yang baik memiliki kualitas bangunan yang baik dan memiliki artian bahwa bangunan tersebut diperhatikan dalam berbagai macam aspek sehingga mengeluarkan kualitas bangunan yang baik.

\section{- Form Simplicity / Kesederhanaan Bentuk}

Lingkup tapak bentuk hotel Katamama dibatasi oleh batu bata merah dan pepohonan. Bentuk tersebut memperlihatkan sisi ketertutupan dengan wilayah di sekitarnya. Lingkup tapak mengikuti bentuk bangunan Hotel Katamama. Bangunan tidak memiliki taman terbuka untuk umum, sehingga suasana privat sudah ditampilkan pada suasana lingkung tapaknya. Suasana privat menjadi penekanan pada hotel, karena merupakan salah satu ciri khas Hotel Katamama.

Arsitek Hotel Katamama dalam salah satu wawancara mengatakan bahwa massa bangunan hotel dibuat untuk menyeimbangkan lingkungan di sekitar Potato Head. Sebelah barat Hotel Katamama merupakan tempat klub pantai bernama Potato Head Beach Club. Tempat klub pantai tersebut merupakan bagian dari wilayah Potato Head yang sudah lama berdiri sebelum Hotel Katamama dibangun. Hotel Katamama dibuat dengan bentuk yang geometris berguna untuk menyeimbangkan bangunan Potato Head Beach Club yang berbentuk lengkung. 
Selain itu, identitas arsitektur Bali adalah memiliki benteng yang tinggi sebagai pembatas tapak. Hotel katamama tidak memiliki benteng/tembok penyengker untuk menutupi seluruh tapaknya (benteng dipakai di sebagian tapak), karena letaknya yang bersamaan dengan bangunan komerisal lain yang dimiliki oleh satu perusahaan yaitu PTT Family. Selain itu, tembok penyengker memiliki hitungan tersendiri dalam proses pembuatannya, serta memiliki arti spiritual, sedangkan benteng pada Hotel Katamama tidak memiliki arti lain selain sebagai pelingkup sebagian hotel. Oleh karena itu, bentuk lingkup tapak dan massa bangunan Hotel Katamama tidak bertujuan untuk menampilkan identitas lokal seperti bentuk massa yang mengarah ke gunung, ataupun sumbu yang disusun secara diagonal, sesuai dengan arsitektur Bali. Tapak Hotel Katamama tergabung dengan bagian dari Potato Head yang lain, sehingga kesimetrisan lingkup tapak yang menunjukkan ekspresi identitas lokal Bali tidak dapat terlihat.

\section{- Visual Scope}

Kualitas yang memberikan pandangan visual dengan makna mendalam, yang tidak tampak dengan pemikiran selewat, tapi diperhatikan dan diperlihatkan secara tidak langsung melalui makna simbolis. Hal ini termasuk dengan pemandangan yang tersembunyi dalam bangunan, keheningan, atau sesuatu makna yang tersembunyi. Visual scope yang ada pada lingkup tapak terlihat dari area pedestrian yang menuntun ke arah masuk tapak. Bagian kiri area pedestrian berupa pepohonan, sedangkan bagian kanannya berupa dinsing bata. Visual scope memberikan pandangan visual yang memberikan makna seolah-olah pengunjung "dibimbing" untuk masuk ke area masuk tapak.
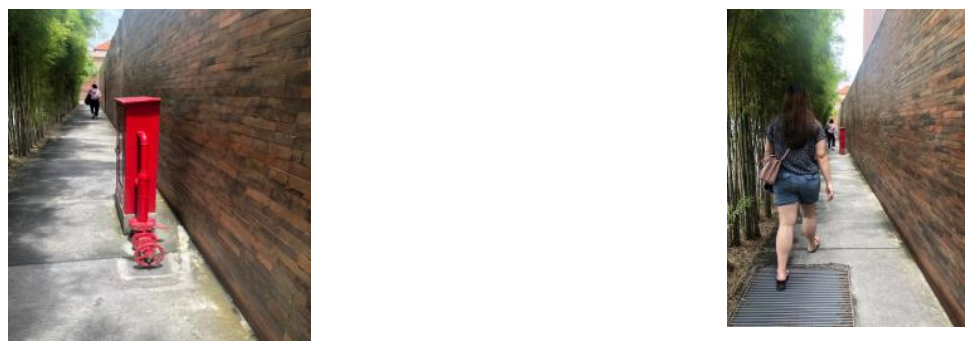

Gambar.4 Area Pedestrian Menuju Hotel Katamama

Identitas lokal yang ditunjukan tidak terlihat pada bagian ini karena tidak memperlihatkan interaksi antara manusia dengan hubungan spiritual. Pada arsitektur Bali, terdapat tembok/benteng yang menjadi batas tapak satu dengan tapak lain. Bagian ini tidak ditunjukkan oleh Hotel Katamama. Identitas lokal Bali pada lingkup tapak berada pada benteng tinggi yang membatasi tapak satu dengan tapak yang lain. Hal itu memberikan kesan aman pada penghuni rumah. Benteng/tembok penyengker juga memberikan kesan bahwa fungsi bangunan tersebut adalah fungsi yang privat dan dipercayai memiliki makna spiritual.

\section{- Directional Differentiation}

Hotel Katamama hanya memiliki satu area masuk untuk para pengunjung, sehingga muka bangunan berada pada bagian area masuk pengunjung. Tampak kiri, kanan, dan belakang bangunan memiliki tampak yang berbeda.
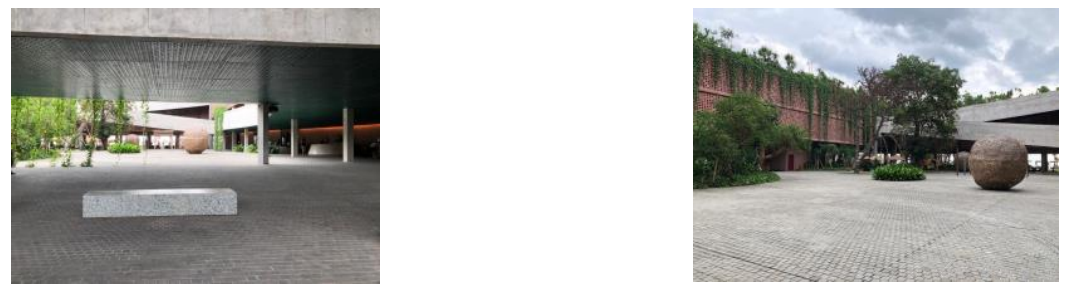

Gambar.5 Hall Tengah Potato Head 
Ada 2 jalur untuk mencapai Hotel Katamama dari bagian depan komplek Potato Head, yaitu melalui area untuk menurunkan pengunjung (drop off), dan dari area parkir. Ketika pengunjung masuk memalui jalur drop off, hotel sudah terlihat, sehingga dekat dengan area lobby hotel. Ketika pengunjung dari area parkir, pengunjung melalui hall tengah Potato Head, dimana sekarang menjadi hall tengah Potato Head Studio, sekaligus menjadi pembatas antara Potato Head Studio dengan Hotel Katamama. Oleh karena itu, pengunjung yang datang dari area parkir akan sulit untuk mengetahui arah (directional differentiation) ke Hotel Katamama. Identitas Bali tidak ditunjukkan dalam bagian ini karena tidak menunjukkan adanya interaksi antara masyarakat Bali dengan hubungan keTuhanan. Arsitektur Bali mengutamakan keutamaaan keTuhanan lewat area penyembahan yang diletakan menghadap gunung/utara, sedangkan arsitektur Hotel Katamama tidak mengindahkan pembedaan arah tersebut.

\section{- Dominance}

Dominasi pada lingkup tapak menjadi sulit dan tidak memiliki banyak dominasi, karena lingkungan tapak bersatu dengan bangunan Potato Head yang lain, sehingga dominasi yang ditunjukkan hanya elemen lansekap, yaitu rumput dan pepohonan. Dominasi yang dirasakan pada lingkup Hotel Katamama terlihat dari material dan elemen hijau yang digunakan di sekitar tapak. Elemen hijau cukup banyak digunakan sehingga suasana alam terasa di lingkungan sekitar hotel, dan dinding batu bata yang ada pada lingkup tapak. Dominasi identitas arsitektur Bali pada lingkup tapak yaitu adanya benteng masif yang ada pada setiap rumah di Bali. Benteng tersebut mengekspresikan ketajaman batas, keprivasian penghuni rumah dan tamu yang datang, serta kesan yang terutup. Selain itu, sebagian besar rumah tradisional Bali juga didominasi oleh banyaknya dekorasi ornamen dan tembok penyengker pada tapaknya.

\subsection{BENTUK BANGUNAN}

Analisa ekspresi yang akan diteliti pada bentuk bangunan mengacu pada teori Kevin Lynch tentang Teori Kualitas Bangunan yang dikaji dengan objek penelitian, yaitu Hotel Katamama di Seminyak, Bali dan mengetahui identitas lokal yang ada pada bentuk bangunan Hotel Katamama.

\section{- Form Simplicity}

Bentuk luar hotel yang geometeris tidak sesuai dengan bentuk dalamnya yang bersusun diagonal. Kesederhanaan bentuk yang dimaksud ini berfungsi untuk memberi kemudahan akses pada pengunjung yang dapat dilihat dan dipahami, salah satunya dari susunan ruangnya. Susunan ruang ini ikut berperan penting dalam menentukan bentuk bangunan. Susunan diagonal diterapkan di seluruh lantai, sehingga menjadi bentuk yang dominan pada bangunan. Susunan diagonal tersebut membuat bagian ruang termasuk bagian servis dan sirkulasi vertikal memiliki ruang dengan susunan yang diagonal. Susunan diagonal yang dibuat menjadikan pengolahan bagian ruang yang tidak efektif, karena terdapat beberapa ruang yang memiliki ruang mati, karena adanya bagian lancip yang membuat area ruang tidak bisa digunakan, termasuk berdampak pada keefektifan ruang kamar.

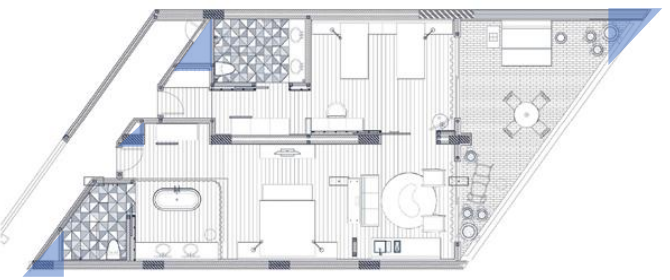

Gambar.6 Sudut Runcing pada Tipe Kamar Two Bedroom Suites 


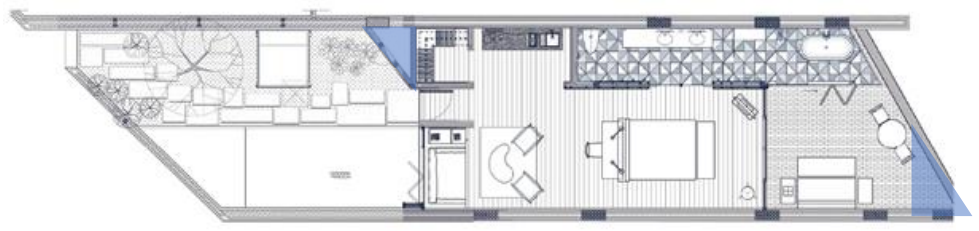

Gambar. 7 Sudut Runcing pada Tipe Kamar The Pool Suites

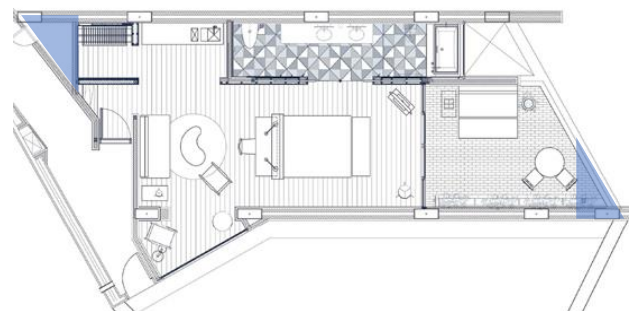

Gambar.8 Sudut Runcing pada Tipe Kamar The Island Suites

Identitas lokal Bali pada kesederhanaan bentuk/form simplicity terdapat juga pada prinsip dasar/ordering principles pada bagian sumbu. Susunan diagonal pada arsitektur Bali memberi makna mengarah dari arah nista ke arah yang utama/suci, dengan menggunakan ruang utama sebagai tempat penyembahan, sedangkan susunan ruang Hotel Katamama tidak memiliki makna tersebut. Hotel Katamama memiliki sumbu yang bersusun diagonal, akan tetapi susunan tersebut memiliki pengertian dan makna yang berbeda dengan identitas yang ditampilkan pada arsitektur Bali. Susunan diagonal pada Hotel Katamama digunakan sebagai elemen estetika, bukan memiliki arti sebagai pengutamaan terhadap keTuhanan.

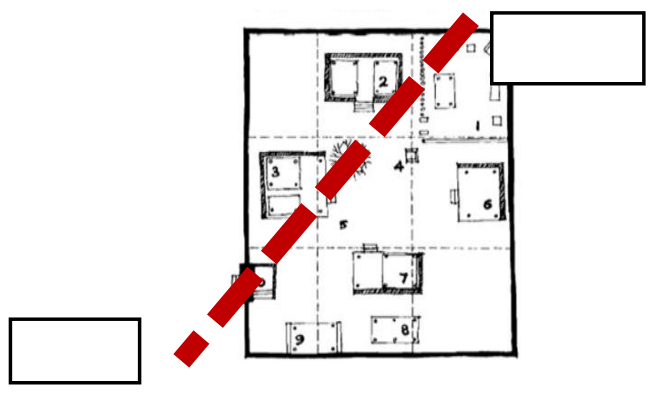

Gambar.9 Susunan Diagonal pada Arsitektur Bali

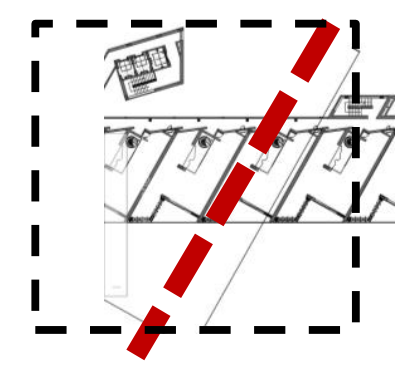

Gambar. 10 Susunan Diagonal pada Denah Tipikal Hotel Katamama

Salah satu ciri khas lain bangunan Bali dapat ditemukan lewat prinsip dasar simetri. Arsitektur Bali memiliki kesimetrisan bentuk, lewat bangunannya yang berbentuk bujur sangkar. Bentuk bujur sangkar ini memiliki kesimetrisan pada bentuknya. Hotel Katamama tidak memiliki kesimetrisan bentuk, yang mana hal tersebut tidak menunjukkan identitas lokal arsitektur Bali. Adanya pemberitaan bahwa eksterior bangunan Hotel Katamama menunjukkan adanya konsep Tri Angga karena menunjukkan keharmonisan tidak dapat dibenarkan. Hal itu karena konsep Tri Angga tidak hanya berkenaan dengan keharmonisan saja, tetapi harus dibuktikan dengan adanya zoning nista, madya, dan utama yang menjadi dasar konsep Tri Angga tersebut.

\section{- Visual Scope}

Sirkulasi koridor Hotel Katamama dibuat dengan material bata Bali yang merah kegelapan membawa suasana diam dan tenang pada hotel dengan balutan desain yang modern. Identitas lokal Bali pada bagian lingkup visual ini tidak diterapkan, karena tidak menunjukkan adanya interaksi anatara masyarakat dengan hubungan spiritual. Ketenangan yang diciptakan oleh Hotel katamama dengan permainan terang, gelap dan permainan susunan bata tersebut 
dibuat pada bagian koridor menuju ruang kamar, bukan dibuat untuk area penyembahan, sedangkan area penyembahan yang menjadi bagian yang diutamakan pada identitas lokal Bali.

\section{- Directional Differentiation}

Bentuk bangunan sendiri tidak memberikan penunjuk arah yang mengarah ke bagian Hotel Katamama. Identitas lokal Bali tidak ditampilkan pada aspek bentuk bangunan. Bentuk bangunan yang tidak simetris, dengan banyaknya bentukan masif membuat pengunjung sulit untuk mengenali fungsi bangunan, yaitu fungsi hotel. Arsitektur Bali membuat sumbu yang mengarah ke pamerajan. Bentuk bangunan Hotel Katamama tidak menunjukkan adanya pembeda arah yang menunjukkan ke bagian area yang lebih suci, ataupun mengarah ke gunung/laut. Gunung dan laut adalah arahan yang selalu dijadikan patokan oleh masyarakat Bali (orientasi kosmologi).

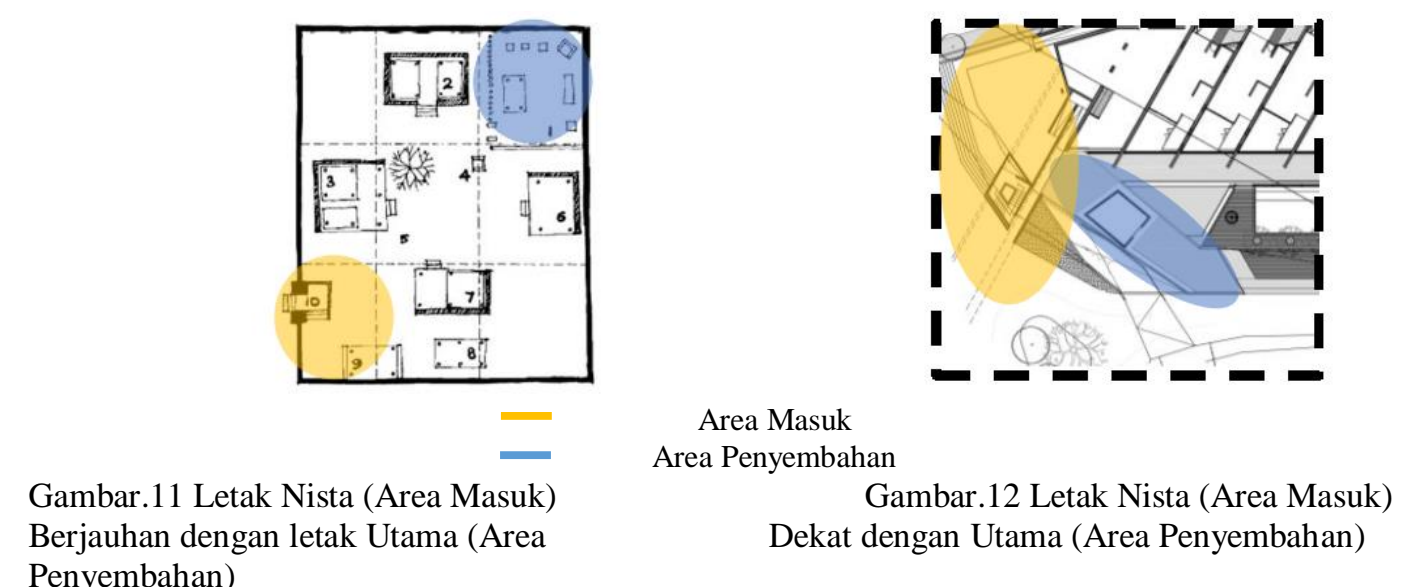

Identitas lokal Bali dapat ditunjukkan dengan prinsip dasar/ordering principles hiraki. Hirarki ini ditunjukkan dengan adanya pengutamaan dengan keTuhanan. Pengutamaan ini bisa ditunjukkan lewat arah yang menunjukkan ekspresi interaksi manusia dengan lingkungan fisik dan spiritual. Hubungan antara lingkungan fisik dengan area penyembahan di Hotel Katamama tidak memiliki interaksi yang kuat. Hal ini dikarenakan area penyembahan dengan area pengunjung memiliki arah yang berbeda, sehingga tidak terjadi interaksi yang membuat hubungan antara manusia dengan lingkungan spiritual tidak memiliki kesatuan. Oleh karena itu, ekspresi lingkup visual pada Hotel Katamama tidak menunjukkan adanya identitas lokal Bali.

\section{- Dominance}

Dominasi hotel berada pada bagian dinding pada hotel yang tersusun diagonal. Dinding diagonal tersebut bukan hanya berada pada tapak bangunan saja, tetapi juga terletak dan terlihat dominannya pada bagian dalam bangunan. Dinding dengan susunan diagonal tersebut berbeda dengan bentuk hotel yang geometris, sehingga terdapat ketidakharmonisan antara bentuk dengan susunan ruang yang diagonal. Hal ini menjadikkan suatu ciri khas yang membedakan Hotel Katamama dengan hotel pada umumnya. Kedua, dominasi dari material yang digunakan. Material batu bata digunakan di seluruh pelingkup bangunan, termasuk pada bagian kamar. Batu bata ini menggambarkan ciri khas Bali, khususnya menjadi ciri khas Desa Tenganan. Arsitek hotel melihat kesederhanaan Desa Tenganan, salah satunya dengan material batu bata yang digunakan pada rumah di desa tersebut. Desa Tenganan merupakan desa dengan Budaya Bali yang sudah lama ada, arsitektur bangunan yang masih tradisional serta dengan suasana alam pedesaan yang kental, dan belum tersentuh kemajuan zaman. 


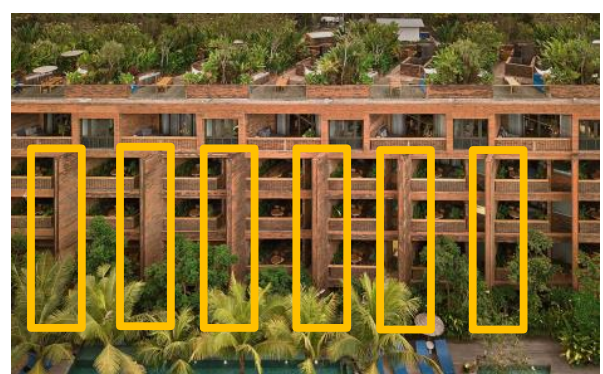

Gambar.13 Dominasi Dinding Diagonal pada Hotel Katamama

Batu bata ini menjadi dominasi yang ada pada Hotel Katamama. Identitas lokal arsitektur Bali yang terdapat pada aspek dominasi dapat dilihat dari material batu bata Bali yang digunakan di seluruh pelingkup bangunan Hotel Katamama. Oleh karena itu, kualitas bangunan dominasi Hotel Katamama hanya terletak pada material yang digunakan, yaitu batu bata Bali yang mencerminkan identitas lokal Bali.

\section{Evaluasi Identitas Lokal}

Budaya Bali tidak dapat dipisahkan dari keutamaannya pada agama, terutama Agama Hindu. Budaya tersebut tercermin dalam kehidupan sehari hari, salah satunya lewat arsitektur. Identitas lokal Bali mengekspresikan interaksi antara manusia dengan lingkungan alam sekitar dan lingkungan spiritual. Ketiga hubungan tersebut harus tercermin dan seimbang, sehingga menghasilkan keharmonisan dalam hidup. Hubungan yang terjalin antara manusia, lingkungan alam sekitar, dan lingkungan spiritual pun harus tercermin pada bangunan di Bali, sebagai sebuah jati diri yang melekat pada kehidupan masyarakat Bali.

Sesuai kajian yang dibahas, yaitu tentang identitas lokal pada ekspresi bangunan Hotel Katamama, mencerminkan bahwa Hotel Katamama tidak mencerminkan identitas lokal Bali secara keseluruhan. Hal tersebut dilihat dari aspek-aspek kualitas bangunan yang dibahas, tidak mencerminkan adanya identitas Bali pada ekspresi Hotel Katamama, yang memperlihatkan adanya interaksi, khususnya antara manusia dengan lingkungan spiritual. Batu bata merah Bali yang menjadi pelingkup bangunan Hotel Katamama merupakan ciri khas Bali dan sesuai dengan ciri khas Bali yang mengutamakan kejujuran materialnya, akan tetapi tidak cukup untuk menggambarkan identitas lokal yang ada pada Hotel Katamama. Ciri khas Bali hanya terdapat pada material yang digunakan, yaitu batu bata Bali. Hal tersebut menjadi disayangkan karena Hotel Katamama memiliki potensi yang kuat, untuk bisa menunjukkan identitas Bali lewat konsep Bali pada bangunannya, seperti konsep orientasi kosmologi yang menjadi bagian dalam konsep Sanga Mandala, konsep Tri Angga, dan kosep Tri Hita Karana

Pertama, lokasi hotel yang berdekatan dengan laut dapat dijadikan salah satu patokan menggunakan konsep kosmologi. Konsep kosmologi yaitu konsep Bali yang berhubungan dengan laut dan gunung. Kebudayaan Bali memiliki kepercayaan bahwa susunan ruang berdasarkan sumbu bumi, yaitu kaja/gunung dengan kelod/laut, memberikan nilai utama pada arah kaja (gunung) dan nista pada arah kelod (laut), sedangkan berdasarkan sumbu matahari, nilai utama pada arah matahari terbit dan nista pada arah matahari terbenam. Hotel Katamama memiliki arah yang sama antara laut dengan arah matahari terbenam. Hal tersebut menjadi sebuah kesempatan untuk menggunakan konsep orientasi Kosmologi. 


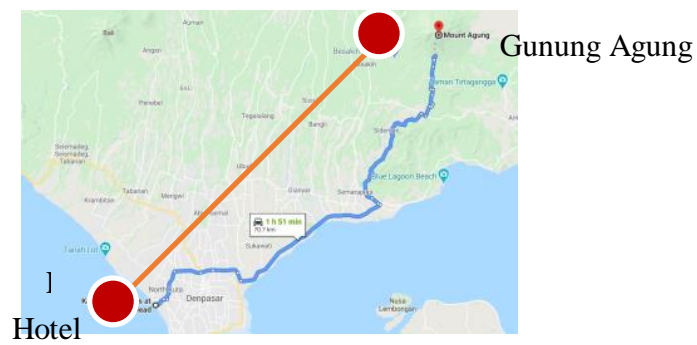

Gambar.14 Posisi Gunung Agung,Hotel Katamama, dan Laut

Kedua, konsep Tri Angga dapat digunakan dalam susunan ruangnya. Konsep Tri Angga yaitu konsep Bali yang mengutamakan keselarasan dan keharmonisan dalam pembagian ruangnya. Bagian nista, dapat dijadikan sebagai area dimana pengunjung datang/ biasa disebut dengan area entrance, dan ruang servis seperti: toilet umum, gudang, $\mathrm{BOH}$ (Back of The House), dan ruang utilitas. Bagian madya merupakan tempat aktivitas manusia, dalam fungsi hotel dapat dijadikan sebagai ruang-ruang kamar sebagai tempat aktivitas dimana pengunjung dapat mengabiskan waktu lebih banyak. Bagian utama dijadikan sebagai area penyembahan, dimana menjadi bagian penting karena menyangkut hubungan antara manusia dengan keTuhanan.

Sekarang ini, pura yang ada di Hotel Katamama tidak menghadap ke arah Gunung Agung, arah utara, maupun arah matahari terbit. Pura yang ada di Hotel Katamama menghadap ke arah timur. Hal itu menunjukkan bahwa Hotel Katamama tidak menggunakan orientasi kosmologi dalam penggunaan ruangnya. Posisi pura yang ada di Hotel Katamama terbilang tersembunyi, dimana pura ditutupi oleh pepohonan yang rindang, sehingga tidak ada yang menyadari bahwa terdapat pura pada bagian depan hotel. Posisi pura berada di bagian depan bangunan. Bagian depan bangunan yang dimaksud yaitu tempat area masuk pengunjung. Hal tersebut bertentangan dengan zona Tri Angga, dimana posisi utama (pura) harusnya terletak di bagian yang paling ujung, berjauhan dengan posisi nista.
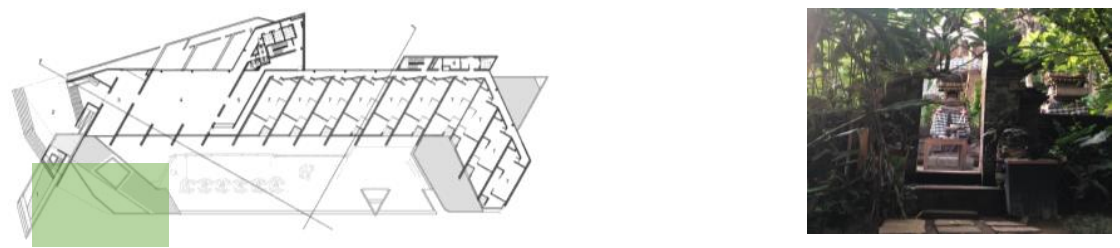

Gambar. 15 Tempat Penyembahan yang Terletak pada Hotel Katamama

Ketiga, konsep Sanga Mandala banyak diterapkan pada perumahan permukiman di pulau Bali. Salah satu konsep yang sangat berbeda yaitu massa bangunannya. Pada bagian fisiknya, Sanga Mandala memiliki beberapa massa yang terpisah, sedangkan Hotel Katamama hanya memiliki satu massa. Bagian tengah konsep Sanga Mandala berupa natah, yaitu area terbuka yang ada di tengah-tengah massa bangunan, sedangkan bangunan hotel ini massif, tidak terdapat pekarangan tengah pada bangunannya.

\section{KESIMPULAN}

Budaya Bali tidak dapat dipisahkan dari keutamaannya pada agama, terutama Agama Hindu. Budaya tersebut tercermin dalam kehidupan sehari hari, salah satunya lewat arsitektur. Identitas lokal Bali mengekspresikan interaksi antara manusia dengan lingkungan alam sekitar dan lingkungan spiritual. Ketiga hubungan tersebut harus tercermin dan seimbang, sehingga menghasilkan keharmonisan dalam hidup. Hubungan yang terjalin antara manusia, lingkungan 
alam sekitar, dan lingkungan spiritual pun harus tercermin pada bangunan di Bali, sebagai sebuah jati diri yang melekat pada kehidupan masyarakat Bali.

Identitas lokal diterapkan pada bagian dominan/dominance pada bangunan. Sesuai kajian yang dibahas, yaitu tentang identitas lokal pada ekspresi bangunan Hotel Katamama, mencerminkan bahwa Hotel Katamama tidak mencerminkan identitas lokal arsitektur Bali secara keseluruhan. Hal tersebut dilihat dari aspek-aspek kualitas bangunan yang dibahas, tidak mencerminkan adanya identitas Bali pada ekspresi Hotel Katamama, yang memperlihatkan adanya interaksi, khususnya antara manusia dengan lingkungan spiritual. Batu bata merah Bali yang menjadi pelingkup bangunan Hotel Katamama merupakan ciri khas Bali dan sesuai dengan ciri khas Bali yang mengutamakan kejujuran materialnya, akan tetapi tidak cukup untuk menggambarkan identitas lokal Bali yang ada pada Hotel Katamama.

Identitas lokal pada ekspresi yang ada pada Hotel Katamama hanya berada pada penggunaan material batu bata merah. Lingkup tapak hingga bentukan/layout ruang tidak menunjukkan adanya penggunaan konsep Bali. Oleh karena itu, adanya suatu berita yang membicarakan bahwa Hotel Katamama memiliki konsep Tri Angga pada eksteriornya adalah pernyataan yang perlu dipertanggungjawabkan, karena tidak menunjukkan adanya konsep tersebut pada bagian hotel, baik eksterior maupun interiornya. Konsep keselarasan dan keharmonisan pada Konsep Tri Angga dibuktikan dengan adanya 3 bagian/zoning, yaitu: utama, madya, dan nista pada bangunan, karena jika terpatok pada keselarasan dan keharmonisan saja, maka hasilnya berupa pernyataan yang relatif dan tidak bisa dibenarkan.

\section{DAFTAR PUSTAKA}

Arjana, Bagus Made. 2014. Perkembangan Variasi Bentuk dan Spatial Angkul-Angkul, Telajakan dan Tembok Penyengker di Denpasar. Majalah Ilmiah Universitas Dwijendra, ISSN. No. 0852-7768, Agustus 2014

Bandem, Putu Dupa. (2012). Tri Hita Karana dan Tat Twam Asi sebagai Konsep Keharmonisan dan Kerukunan. Diakses tanggal 4 Februari 2020, dari https://pandejuliana.wordpress.com/2012/01/20/tri-hita-karana-dan-tat-twam-asi/

Bentley, Ian, dkk. 1992. Lingkungan yang Tanggap, Sebuah Pedoman bagi Perancang. Penerbit Intermatra, Bandung

Boedjojo, Poedio, dkk. 1986. Arsitektur, Manusia, dan Pengamatannya. Djambatan, Jakarta

Ching, Frank. 2007. Architecture - Form, Space \& Order. New Jersey: John Wiley \& Sons, Inc.

Dwijendra, Ngakan Ketut Acwin. 2008. Arsitektur Rumah Tradisional Bali: Berdasarkan Asta Kosala-Kosali. Denpasar: Udayana University Press dan CV. Bali Media Adhikarsa Francis, G. Caro. 1971. Readings in Evaluation Research. New York

I.B.G. Pujaastawa. (2014). Kebudayaan Bali. Makalah.

Katamama - Arsitektur Indonesia (2016). Diakses tanggal 8 Mei 2020, dari http://www.arsitekturindonesia.org/arsip/proyek/detail?oid=9

Katamama / Andramatin (2016). Diakses tanggal 8 Mei 2020, dari https://www.archdaily.com/791287/katamama-andra-matin

Koentjaraningrat. 2009. Pengantar Ilmu Antropologi. Jakarta: Universitas Indonesia Press. Lynch, Kevin. 1960. The Image of the City. MIT Press, Cambridge

Ratnatami, Ariko. 2005. "Aspek Bentuk Arsitektur Bangunan pada Makna Fungsi Bangunan dan Ekspresi Arsitektur Kawasan Koridor (Studi Kasus: Koridor Jl. Jend. Sudirman, Surakarta)". Tesis. Teknik Arsitektur. Universitas Diponegoro. Semarang.

Salura, P. (2012). Sintesis elemen Arsitektur Lokal dengan Non-Lokal, Kasus studi: Gedung Sate di Bandung, Gedung UPS di Tegal. Bandung: Universitas Katolik Parahyangan. 
Subawa, I Made Pasek. (2018). Bali dalam Dinamika Masyarakat dan kebudayaan di Tengah Perkembangan Pariwisata. Pariwisata Budaya. Vol.3, No 1, 95-98

Sujana, Nyoman Naya. 1994. Manusia Bali Dipersimpangan Jalan. Denpasar: Balai Pustaka

Tanuwidjaja Gunawan, Aryani Ni Putu. 2013. Sustainable Architectural Design Traditional Balinese Housing In Accordance To The Concept Of Tri Mandala. 